\title{
THE STABILITY OF LONG-RUN MONEY DEMAND IN WESTERN BALKAN COUNTRIES: AN EMPIRICAL PANEL INVESTIGATION
}

Jordan Kjosevski, Mihail Petkovski, Elena Naumovska

\section{Abstract}

The goal of this paper is to examine the stability of money demand (M1) in five Western Balkan countries using quarterly data from 2005Q1 to 2014Q4. The dynamic ordinary least squares - DOLS method was used to find the long-run relationships in a money demand model. The empirical results identify the long-run money demand relationship among real M1 nominal interest rate, exchange rate, inflation and a dummy variable for the effect of the European debt crisis. The estimated long-run coefficients are, respectively -0.086, 0.519, 0.002 and 0.030 . Our findings imply that real money demand in Western Balkan countries was stable in the analyzed period.

Keywords: money demand, cointegration, dynamic ordinaryleast squares, stability, Western Balkan countries

JEL classification: C32, E41, E52

\section{INTRODUCTION}

Money demand is one of the most important components of monetary policy transmission mechanisms in a market economy. According to Cziraky and Gillman (2006), a stable money demand allows for better predictions of monetary policy effects on interest rates, output, and inflation, and reduces the possibility of an inflation bias.

The importance of the money demand function has encouraged a wide range of economists to empirically study its determinants. But, while money demand literature has focused on developed countries, there have been relatively few studies examining the money demand function in transition countries and especially in Western Balkan countries (namely, Albania, Bosnia and Hercegovina, Croatia, Macedonia and Serbia). These countries in the past two decades have been undergoing a transition from a centrallyplanned to a market economy, and reforms for monetary policy implementation have been part of this process.

Similar to other economies, the Western Balkan region was affected by the collapse of global demand that followed the Lehman Brothers bankruptcy in September 2008. However, after the rather sharp drop of output in 2009, all five economies recovered quickly in 2010. Then, under the impact of the European debt crisis, the Western Balkan countries experienced a double-dip recession in 2012. They have recovered

\section{Jordan Kjosevski, PhD}

Independent Researcher

E-mail:jordan_kos@yahoo.com

\section{Mihail Petkovski, PhD}

Faculty of Economics, Ss Cyril and Methodius University in Skopje

E-mail:mpetkovski@eccf.ukim.edu.mk

\section{Elena Naumovska, PhD}

Faculty of Economics, Ss Cyril and Methodius University in Skopje

E-mail: elenan@eccf.ukim.edu.mk 
slowly and the exit from recession was especially hard for Serbia and Croatia (Croatia recorded negative growth rates for the whole period 2011-2014).

Thus, the main objective of this paper is to estimate a long-run money demand function in selected Western Balkan countries. Because the selected countries are transition economies and have to manage enormous structural changes, it is difficult to obtain data for a longer period. The estimated parameters, which are based on a short period, are not very reliable. Evidently, estimates for long-run parameters require more data for a long period. Alternatively, the sample can be extended if the information of all countries is pooled (Dreger, Reimers, and Roffia 2007). This is done by panel integration and cointegration techniques (Banerjee 1999). Specifically, the procedures of Pedroni (2000), Mark and Sul (2003) are used to get efficient estimates of the long-run parameters.

The structure of the paper is as follows. After the Introduction, Section 2 reviews the literature on empirical findings relevant to the determinants of money demand. The sources for the data used as well as methodology are presented in Section 3. Section 4 presents the empirical results and section 5 concludes the paper and gives policy recommendations.

\section{LITERATURE REVIEW}

There are only several papers on money demand in Western Balkan countries, including Anusic (1995), Sonje (1999), Babic (2000), Maravić and Palić (2005), Kalrla (1998), and Kjosevski (2013). We will briefly review some of these papers.

Maravić and Palić (2005) analyzed the long-term and short-term money demand in Serbia for the period January 1996 to March 2005, using a Johansen cointegration technique and VECM model. As an indicator of the real money demand they use real M1. The cointegration analysis shows that there is a strong cointegration relationship between real money, overall economic activity, inflation and interest rate on deposits in dinars. The short-term model (ECM) suggests that the most important determinants of real money demand are inflation and exchange rates. Their analysis finds that the interest rate on dinar deposits is not a statistically significant determinant and does not have a significant impact on money demand. The results of the empirical analysis suggest that money demand was unstable in the analyzed period.

Among the first analyses that explore the demand for money in Croatia are Anusic (1994), Sonje (1999), Babic (2000). Anusic (1994) employs the method of ordinary least squares, using monthly data from January
1991 to November 1993. The results of the study indicate that the main determinants of money demand in a period of hyperinflation in Croatia were inflation and real economic activity, while the interest rate has no significant impact on the demand for money. On the other hand, Sonje (1999), analyzed money demand in the period after hyperinflation, proving empirically that inflation no longer had a significant effect. In his study, Babic (2000) also suggests that inflation is not a statistically significant variable and has no impact on the demand for money in Croatia.

Karla (1998) estimates the relationship between money, inflation, prices, exchange rate, and interest rate in Albania during 1993-1997, using a parsimonious error correction model. She finds that in the long run there is a positive relationship between the price level and the exchange rate, and between real money demand and exchange rate expectations, interest rates and the level of economic activity.

Kjosevski (2013) applies a Johansen cointegration technique and VECM model to estimate money demand in the Republic of Macedonia, using monthly data from January 2005 to October 2012. The empirical results in his paper provide evidence that exchange rate and interest rate payable on denar time deposits up to one month explain most variations in money demand in the long-run, while the interest rate is significant only in the short-run. His findings show that real money demand M1 in the Republic of Macedonia was stable in the analyzed period.

Ivanov, Petkovski and Naumovska (2015) also investigate the money demand estimations in Macedonia for the period from 2002 to 2012, using a cointegration approach. They applied a broader measure of money demand (M2 aggregate) and found that the estimated income elasticity was less than unity $(0,81)$ and consistent with previous studies in the case of Macedonia. Their results imply that the M2 aggregate may serve as a proper policy indicator.

However, these studies are country-specific studies, and not panel studies. Panel based studies represent an improvement in this respect by exploiting additional information that results from the inclusion of the cross-sectional dimension.

There is only one study Ozturk and Acaravci (2008) that examines a portion of the Western Balkans countries (Bulgaria, Croatia, Macedonia and Romania), to our knowledge. These authors estimate the demand for M2 for a panel of 10 transition countries (Bulgaria, Croatia, Czech Republic, Hungary, Macedonia, Poland, Romania, Russian Federation, Slovak Republic and Ukraine) using data from 1994-2005 with feasible generalized least squares. The results show that the demand for money and quasi money (M2) is positively 
related to real GDP and negatively to inflation rate and the real effective exchange rate. The estimated common long-run income elasticity for the ten transition economies is about unity.

The main contribution of this study is to provide new insights into the origins, characteristics and consequences of long-run determinants of money demand in Western Balkan economies. Namely, most studies focus on individual country cases, and to the author's knowledge there are none for this region. Moreover, the existing panel studies (Kumar 2010; Nautz and Rondorf 2011) usually consider only several variables (e.g. income, prices and a measure of the opportunity costs) in the money demand equation. However, in the period of transition exchange rate can also play a crucial role in explaining money demand. Namely, during periods of high inflation, the Western Balkan countries experienced a partial replacement of domestic by foreign currencies, either as a store of value or a medium of exchange. Also, all selected countries from the Western Balkans are "small" open economies, and foreign trade liberalisation during the transition process has therefore affected country behaviour with respect to their demand of foreign and domestic financial assets. These countries could switch more easily between foreign and domestic currencies. This may have affected money holdings in these economies. Therefore, the exchange rate is likely to be an important factor in explaining money demand behaviour in these countries and will be used in the analysis.

\section{MODEL SPECIFICATION AND DATA}

Following earlier works on the money demand function such as Arango and Nadiri (1981), Stock and Watson (1993), Ericsson (1998) and Mark and Sul (2003), the empirical model of the money demand can be summarized by the following function:

$$
\frac{M}{P}=F(Y, O C)
$$

where $M$ denotes nominal money, $P$ price level, $Y$ a scale variable representing the transaction volume in the economy and $O C$ denotes the opportunity costs of holding money.

Before crossings to identify potential determinants of money demand it is necessary to identify the dependent variable. Different authors use different measures for money in their studies. In the literature, a narrower concept of money supply is often used for economies with a relatively underdeveloped financial systems (Payne 2003; Skrabic and Tomic-Plazibat 2009). Bearing in mind the current development of the banking and financial systems in the Western Balkan countries, as a measure for money in these paper we use the M1 monetary aggregate, which covers currency in circulation and sight deposits. We then deflate $\mathrm{M} 1$ with the consumer price index (CPI) to get the measure of the real money balance of M1. The use of a narrow monetary aggregate has several other advantages. First, M1 is a good measure of liquidity in the economy, since it consists mainly of financial assets held for transaction purposes. Second, the central bank is able to control this aggregate more accurately than broader aggregates, such as M2 and M3 (Dobnik 2011). Third, M1 definitions tend to be relatively consistent across countries and therefore allow straight comparisons (Bruggeman 2000).

Some authors indicate that using GDP as a measure of economic activity leads to overestimation of the level of transactions in the economy and suggest alternative measures, such as the level of consumption (Mankiw and Summers 1986) or the index of industrial production (Payne 2000; 2003; Skrabic and Tomic-Plazibat 2009). Judd and Scadding (1982) show that the search for an alternative measure of the transactions level does not lead to improvement in the money demand function estimate. For the purposes of our study we follow Payne $(2000,2003)$, Skrabic and Tomic-Plazibat (2009) and use an index of industrial production. For this variable we expect a positive association with money demand.

According to Payne (2003), the exchange rate is an important factor for money demand in transition economies. However, the effect of the exchange rate on money demand is not entirely clear. On the one hand, in a monetary model of the exchange rate, a depreciation of the domestic currency is likely to induce extra demand for domestic goods from abroad, and an induced rise in domestic production implies higher domestic inflation rate and a need for more money in the economy as the amount of transactions increases (Komárek and Melecký 2001). Hence, the effect of the exchange rate in the model should be positive. On the other hand, according to the currency substitution approach by Calvo and Rodriguez (1997), depreciation reduces confidence in the domestic currency, thereby lowering money demand via a substitution effect with foreign money. Hence, its coefficient should be negative. According to the above mentioned studies, the real exchange rate effect is ambiguously related to money demand. It should be noted that as a determinant of the exchange rate in this paper we use the nominal exchange rate of domestic currencies per Euro. 
To measure opportunity cost we use a nominal (domestic) short-run interest rate from the Central Banks of the selected countries. We used interest rate on central bank bills, i.e. the rates that they pay to commercial banks. We could not use the interest rates on bonds, because central banks do not issue longer term financial instruments. We choose this variable because according to Ericsson (1998) long-run rates should not be included in the model for money demand when one uses the M1 monetary aggregate. Also, Komárek and Melecký (2001) suggest that the portfolio motive of holding such money plays only a minor role relative to the transaction motive. For this variable, we expect a negative correlation between central banks short run interest rates and money demand.

The next variable used in our research is the inflation rate. It is used to measure the monetary stability of the country. This variable is expressed by annual increase in CPI (annual percentage base $2005=100$ ). We follow Valadkhani (2008), Ozturk and Acaravci (2008) and Dobnik (2011), who although including inflation in real $\mathrm{M} 1$, also included this variable as an independent determinant.

The negative impact of inflation had been widely documented in previous research, such as Hosein (2007), Mehrotra (2008), Dreger and Wolters (2009). Therefore, we also expect a negative relationship with money demand. Given the variables specified above, we construct a panel data regression model as shown below. The real money demand and exchange rate were transformed into natural logs.

$$
\begin{aligned}
& L\left(\mathrm{M}_{i} / C P I_{i}\right)_{t}=\sum_{i=1}^{n=5} \alpha_{0 i}+\beta_{1}\left(I I P S_{i}\right)_{t}+ \\
& \beta_{2} L\left(E X R S_{i}\right)_{t}+\beta_{3}\left(N I R A T E_{i}\right)_{t}+\beta_{4}\left(\text { INFS }_{i}\right)_{t}+ \\
& \beta_{5}\left(D U M_{i}\right)_{t}+\beta_{6}\left(D U M 1_{i}\right)_{t}+\varepsilon_{i t}
\end{aligned}
$$

where,

$i$ denotes a specific country varying from 1 to $5, t$ is time starting from January 2005 to December 2014;

M1t / CPIt = Real money (M1 deflated with consumer price index $\mathrm{CPI}$ );

IIPS=Index of industrial production (base $2005=100$ ) (seasonally adjusted);

EXRS = Exchange rate of domestic currencies per euro (seasonally adjusted);

NIRATE $=$ Nominal interest rate

INF = Rate of inflation. (base 2005=100) (seasonally adjusted);

DUM =effect of the 2008/09 global economic crisis;

DUM1 = effect of the European debt crisis;

$\varepsilon_{i t}$ is a white noise error process;
In order to capture inter-country heterogeneities one can use the fixed effects model, which allows to $\alpha_{0}$ vary across countries by estimating different intercept terms $\left(\alpha_{01}, \alpha_{02}, \ldots . \alpha_{05}\right)$.

For our research we focus on factors that determine money demand in five countries from the Western Balkans (namely, Albania, Bosnia and Hercegovina, Croatia, Macedonia and Serbia). In order to obtain more observations we used quarterly data from 2005Q1 to 2014Q4. The choice of the countries and the time periods in this paper was contingent upon the availability of time series data on all the variables included in the model. A portion of the abovementioned determinants, including the index of industrial production, exchange rate and inflation, are seasonally adjusted using the Tramo-Seats method. We also follow Kjosevski (2013) in our empirical model by including two dummy variables. With DUM we mark the global economic crisis, which has a value of 1 for the period from October $2008 \mathrm{Q} 3$ to December 2009Q4, and 0 for other periods. DUM1 marks the European debt crisis, with a value of 1 for the period from January 2011Q1 to December 2012Q4, and 0 for all other periods. We choose this period to mark European debt crisis because in the period 2011Q1-2012Q4, the European debt crisis had the strongest impact on the countries in our sample, when they experienced a double dip recession. After that, they recovered at different rates, with the exit from recession especially hard for Serbia and Croatia.

Data are obtained from various sources. Data for the dependent determinant M1 is obtained from the websites of the Central Banks of selected countries. The index of industrial production, the consumer price index and inflation are taken from the websites of state statistical offices and the World Bank. Nominal interest rates and the exchange rate of domestic currency per Euro are also taken from the websites of the central banks for the selected countries.

\subsection{Panel unit root test}

Before proceeding to cointegration techniques, we need to verify that all variables are integrated with the same order. According to Campbell and Perron (1991), the standard unit root and cointegration tests can have low power against stationary alternatives for the important cases, Therefore, gains in power are expected, and more reliable evidence can be obtained. In the paper, the IPS (Im, Pesaran and Shin 2003), Fisher-Type test using ADF and PP-test (Maddala and Wu 1999) tests are applied. These procedures allow for deterministic and dynamic effects differing across the panel members. 
In our study we prefer Fisher-type tests because they have more advantages: (1) the cross-sectional dimension can be either finite or infinite; (2) each group can have non-stochastic and stochastic components; and (3) the time-series dimension can vary for each cross-section (Baltagi 2001). Also, the advantage of the Fisher test is that unlike the IPS test, it does not require a balanced panel, and allows the use of different lag lengths in the individual ADF regression. Nevertheless, we will also report the results of the IPS tests in order to provide an additional check for robustness.

\subsection{Panel Cointegration Test}

The concept of cointegration has been widely used in the literature to test for the presence of long-run relationships among variables. Similar to individual unit root tests, cointegration tests in the time series literature suffer from low power when the time horizon is short. Panel techniques may be better in detecting cointegration relationships, since a pooled level regression combines cross-sectional and time series information in the data when estimating cointegrating coefficients.

Pedroni (1995) concentrated on the homogeneity of the two simple variables in his first analysis. Nonetheless, it has some limitations. As a result, Pedroni (2000) developed seven test statistical test models to test the null of no cointegration (Panel v statistic, panel rho-Statistic, Panel PP-Statistic, Panel ADFStatistic Group rho-Statistic Group PP-Statistic Group ADF-Statistic). Pedroni (1995) showes that in terms of testing power, the group-ADF statistic has the best performance in general, followed by the panel-ADF. The panel-variance and group- $\rho$ statistics performed poorly in comparison. The Schwarz Information Criterion (SIC) has been used to determine the optimal lag length (qi) based on the Newey-West method for bandwidth selection using the Bartlett kernel, with individual intercept and trend included.

\subsection{Panel long-run model}

If variables in the empirical model are nonstationary and cointegrated, the next step in this study is to establish a long-run equation for money demand and its determinants.

For the long-run model in this study we employ the dynamic ordinary least squares DOLS procedure developed by Stock and Watson (1993). The DOLS estimator corrects standard OLS for bias induced by endogeneity and serial correlation. First, the endogenous variable (IIPS, EXRS, NIRATE and INF) in each equation is regressed on the leads and lags of the firstdifferenced regressors from all equations to control for potential endogeneities. These leads and lags are used for adjustment and to improve the estimation results. Next, unit root tests are performed on the residuals of the estimated DOLS regression, in order to test whether it is a spurious regression. Finally, the OLS method is applied using the residuals from the first step regression.

The DOLS estimator is preferred to the non-parametric FMOLS estimator because of its better performance. According to Wagner and Hlouskova (2010), the DOLS estimator outperforms all other studied estimators, both single equation estimators and system estimators, even for large samples. Furthermore, Harris and Sollis (2003) suggest that non-parametric approaches such as FMOLS are less robust if the data have significant outliers and also have problems in cases where the residuals have large negative moving average components, which is a fairly common occurrence in macro time series data. Also, Stock and Watson (1993) prove that, as opposed to other estimators, the DOLS procedure does not require that all the individual series in a long-run relationship be integrated of order one, $\mathrm{I}(1)$, as it is also applicable to systems involving variables of different orders of integration (as is the case with the selected variables in our model). In our case, we can write the Stock-Watson DOLS model as follows:

$$
Y_{i t}=\alpha_{i}+\beta X_{i t}+\sum_{j=-q}^{p} c_{j} \Delta X_{i, t+j}+\varepsilon_{i t}
$$

where $i=1, \ldots \ldots . \mathrm{N}$ refers to each country in the panel and $t=1, \ldots \ldots . \mathrm{T}$, denotes the time period

Yt is the dependent variable

$\alpha$ are individual fixed effects

$X$ is a matrix of explanatory variables

$\beta$ is a cointegrating vector; i.e., representing the long-run cumulative multipliers or, alternatively, the long-run effect of a change in $\mathrm{X}$ on $\mathrm{Y}$

$\varepsilon_{i t}$ are the error terms,

$p$ is the lag length of the first differenced of the explanatory variables

$q$ is the lead length of the first differenced of the explanatory variables

When using panel data estimation, choosing between fixed effects and random effects is crucial. The intercepts $\alpha_{i}$ in Equation (3) stand for the parameters that are estimated for each cross-section in a fixed effects estimation, whereas they are assumed 
Table 1: Unit root tests

\begin{tabular}{|c|c|c|c|c|c|c|}
\hline \multirow{2}{*}{$\begin{array}{l}\text { Test } \\
\text { Variable }\end{array}$} & \multicolumn{2}{|c|}{ IPS } & \multicolumn{2}{|c|}{ ADF-Fisher Chi square } & \multicolumn{2}{|c|}{ PP-Fisher Chi square } \\
\hline & Level & $\begin{array}{c}\text { First } \\
\text { Difference }\end{array}$ & Level & $\begin{array}{c}\text { First } \\
\text { Difference }\end{array}$ & Level & $\begin{array}{c}\text { First } \\
\text { Difference }\end{array}$ \\
\hline LM1 & $\begin{array}{r}-0.84608 \\
(0.1988)\end{array}$ & $\begin{array}{r}-7.48786 \\
(0.0000)\end{array}$ & $\begin{array}{r}13.3796 \\
(0.8730)\end{array}$ & $\begin{array}{l}71.1520 \\
(0.0000)\end{array}$ & $\begin{array}{r}16.3288 \\
(0.906)\end{array}$ & $\begin{array}{r}116.2651 \\
(0.0000)\end{array}$ \\
\hline IPIS & $\begin{array}{r}-1.08198 \\
(0.1396)\end{array}$ & $\begin{array}{r}-8.88858 \\
(0.0000)\end{array}$ & $\begin{array}{r}116.8903 \\
(0.0768)\end{array}$ & $\begin{array}{r}887.0884 \\
(0.0000)\end{array}$ & $\begin{array}{l}26.2494 \\
(0.0034)\end{array}$ & $\begin{array}{l}160.649 \\
(0.0000)\end{array}$ \\
\hline LEXRS & $\begin{array}{r}-1.63711 \\
(0.9492)\end{array}$ & $\begin{array}{r}-10.0055 \\
(0.0000)\end{array}$ & $\begin{array}{l}1.73037 \\
(0.9882)\end{array}$ & $\begin{array}{l}88.8547 \\
(0.0000)\end{array}$ & $\begin{array}{l}2.48150 \\
(0.9626)\end{array}$ & $\begin{array}{r}124.738 \\
(0.0000)\end{array}$ \\
\hline NIRATE & $\begin{array}{r}-0.53388 \\
(0.2967)\end{array}$ & $\begin{array}{r}-4.37852 \\
(0.0000)\end{array}$ & $\begin{array}{l}17.3096 \\
(0.0678)\end{array}$ & $\begin{array}{l}34.2094 \\
(0.0000)\end{array}$ & $\begin{array}{r}11.0350 \\
(0.3548)\end{array}$ & $\begin{array}{l}56.9744 \\
(0.0000)\end{array}$ \\
\hline INF & $\begin{array}{r}-2.08980 \\
(0.0183)\end{array}$ & & $\begin{array}{l}22.2726 \\
(0.0137)\end{array}$ & & $\begin{array}{r}31.9360 \\
(0.004)\end{array}$ & \\
\hline
\end{tabular}

Source: Authors' calculations

to be randomly drawn from a certain distribution in random effects estimation. When the sample size consists of a specific set of countries, like a sub-sample of Organization for Economic Cooperation and Development (OECD) countries, fixed effect estimation is appropriate, whereas when the sample size includes randomly chosen countries all around the world, random effect estimation is more suitable (Baltagi 2005).

Therefore, in this study we will choose fixed effects to estimate the parameters in Equation (3). In order to remove the serial correlation, we estimate the longrun covariance by applying the Bartlett kernel and select the leads and lags based on the Akaike information criterion following the suggestion of Kejriwal and Perron (2008).

Next, we examine the structural stability of the error correction model of money demand using the cumulative sum (CUSUM) and cumulative sum of squares (CUSUMQ) of the recursive residuals test, following Brown et al. (1975). These tests are commonly used by authors who explore the demand for money (Bahmani-Oskooee and Shin 2002; Owoye and Onafowora 2007). Both the cumulative sum and the cumulative sum of squares statistics lie within $5 \%$ of critical values, suggesting the long-run model's stability.

\section{EMPIRICAL RESULTS AND DISCUSSION}

In Table 1 we can see the results from the unit root tests. The IPS, ADF and PP-test indicate stationarity at the first differences for the real money. For the Index of industrial production, IPS and both Fisher-type tests, the ADF and PP-test, indicate stationarity at the first differences. For the exchange rate of domestic currency per Euro the IPS test indicates stationarity at level, while only the PP-Fisher test indicates that the interest rate was stationary at level. The nonstationarity of the first differences is always rejected at the five percent level for the IPS and both Fisher-type tests. For the last variable in the model, inflation, only the PP Fisher test indicates stationarity at level. These results allow for the testing of cointegration among the variables and the estimation of money demand functions.

Next, the panel cointegration results in Table 2 show that among the seven panel statistics, the null hypothesis of no cointegration is rejected by six of the seven test statistics at a $1 \%$ level of significance. Therefore, we may conclude that there is a cointegration relationship among the variables.

Table 2: Pedroni panel cointegration test

\begin{tabular}{|l|c|c|}
\hline Tests & Statistic & Probability \\
\hline Panel v-Statistic & -1.654186 & 0.9510 \\
\hline Panel rho-Statistic & -2.688491 & 0.0036 \\
\hline Panel PP-Statistic & -15.62080 & 0.0000 \\
\hline Panel ADF-Statistic & -2.627339 & 0.0043 \\
\hline Group rho-Statistic & -2.327758 & 0.0100 \\
\hline Group PP-Statistic & -24.37897 & 0.0000 \\
\hline Group ADF-Statistic & -2.428900 & 0.0076 \\
\hline
\end{tabular}

Source: Authors' calculations

Due to the fact that the variables included in the model are nonstationary and cointegrated, the dynamic ordinary least squares-DOLS is adopted in this study. The results of DOLS are reported in Table 3. 
Table 3: Long-Run coefficients of money demand in Western Balkan countries

\begin{tabular}{|l|c|c|c|}
\hline Independent variables & Coefficient & Standard errors & P-value \\
\hline IPIS & 0.001 & 0.22 & 0.44 \\
\hline NIRATE*** & -0.086 & 0.07 & 0.00 \\
\hline LEXR*** & -0.519 & 0.03 & 0.01 \\
\hline INF** & 0.002 & 0.08 & 0.06 \\
\hline DUM & -0.153 & 0.33 & 0.46 \\
\hline DUM1** & 0.030 & 0.05 & \\
\hline Country-specific intercept & & & 0.00 \\
\hline Albania & 15.18 & 0.01 & 0.00 \\
\hline Bosnia and Herzegovina & 14.45 & 0.03 & 0.00 \\
\hline Croatia & 12.32 & 0.01 & 0.00 \\
\hline Macedonia & 13.19 & 0.05 & 0.00 \\
\hline Serbia & 15.30 & 0.01 & 0.15 \\
\hline
\end{tabular}

${ }^{*}, *$ and ${ }^{* * *}$ indicates the test statistic is significant at the $10 \%, 5 \%$ and $1 \%$ level.

Source: Authors' calculations

Regarding the nominal interest rate, this study finds that a larger opportunity cost of holding money is connected with lower real balances. More precisely, the nominal interest rate has a statistically significant impact on real money of -0.08 , ceteris paribus, where the negative sign is consistent with theory.

The coefficient on the effective exchange rate is negative and statistically significant. The results indicate that when possible, depreciation of the exchange rate is expected, returns from holding foreign currency will decrease, which will reduce the demand for money. This relationship between money demand and exchange rate is also consistent with the work of Bahmani-Oskooee and Shabsigh (1996), who argued that if a depreciation of domestic currency results in an increase in expectations of further depreciation, the public may decide to hold more foreign currency and less domestic money. The significance of this determinant in the model is confirmed by the high degree of euroization in the selected countries.

The positive sign of the coefficient of inflation was not expected. This sign of this coefficient in our case can be explained by the lack of alterantive assets, which makes currency in circulation, deposits and real assets almost the only possible means of holding wealth.

The results of the second dummy variable is in line with the result of Kjosevski, (2013). The coefficient is statistically significant and indicates a 0.03 higher demand for real M1 money, solely as a result of the
European debt crisis. This result is not surprising, because according to Kjosevski (2013), the European debt crisis and lack of confidence in the Euro triggered a rebound in the demand for domestic currency.

The coefficient of determination is high and explains $98 \%$ of the variance of the independent determinants. The model also passes the Jarque-Bera normality test, suggesting that the residuals are normally distributed.

Since we are particularly interested in whether the estimations achieved are stable over time and therefore useful for forecasting purposes, we proceed with CUSUM and CUSUMQ tests. The result of the test statistics for evaluating the vector stability is presented in Figure 1.

Based on the CUSUM test results, we can say that the demand for $M 1$ monetary aggregate in countries from the Western Balkan is predictable and can be used for the effective implementation of monetary policy. The result of the CUSUMQ test shows that $M 1$ demand functions were unstable at the end of 2012 and at the beginning of 2013, which may imply that the European debt crisis did have a significant impact on the demand for money in the Western Balkan countries. However, this impact on stability was temporary, as stability of the $M 1$ demand is not rejected after the second quarter of 2013. Further, M1 stability is not rejected in the whole-sample period. These results confirm that long-run money demand is stable in the Western Balkan countries. 
Figure 1: CUSUM Statistics

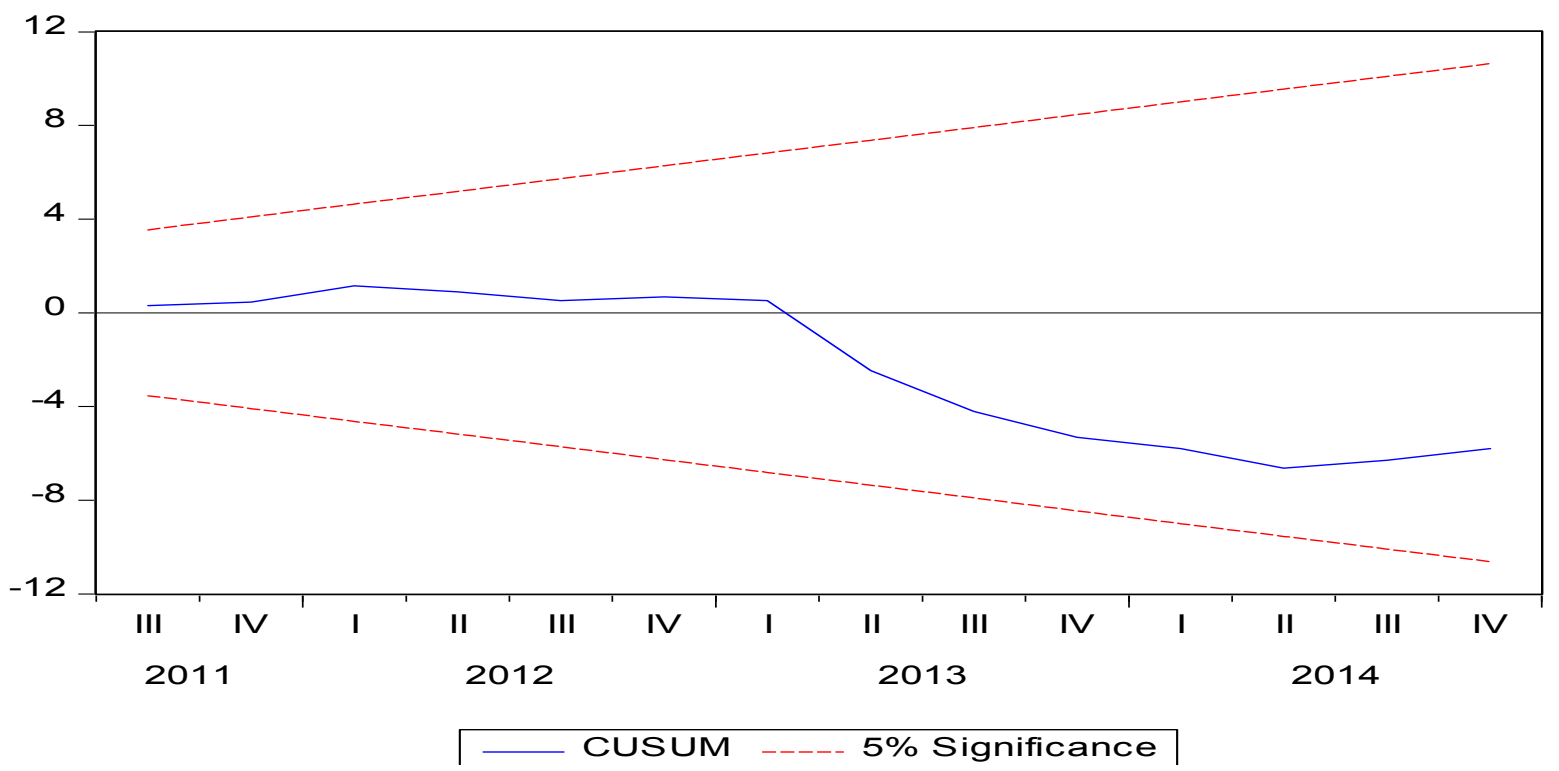

Figure 2: CUSUMQ Statistics

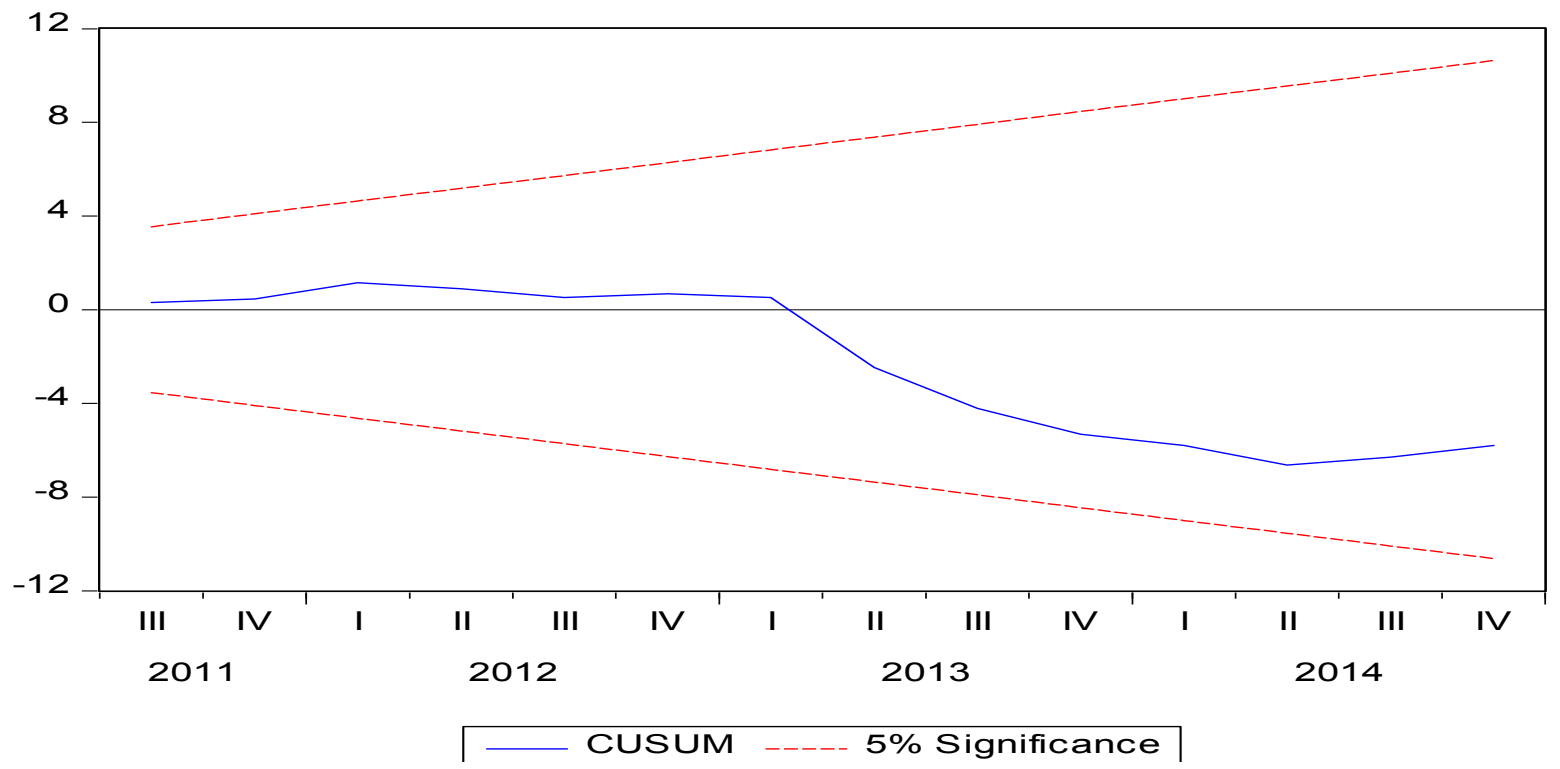

\section{CONCLUSIONS}

Based on the results presented, the hypothesis that the estimated coefficients in the long-run model are stable could not be rejected. The research results indicate that the main forces affecting money demand in the selected Western Balkan countries are the nominal interest rate, the exchange rate of domestic currencies per the Euro and the European debt crisis, which explain most of the variations in money demand in the long run.
This is the first empirical study to analyze money demand in the Western Balkan region, to our knowledge. It complements the existing economic literature by analyzing the determinants of money demand in the five countries from the Western Balkans.

The main constraint of this study is the lack of available data on selected determinants for longer periods. The existence of a long-term series of data would enable obtaining more accurate and more reliable results. In addition, future research and analysis should include other monetary aggregates, such as the M2 
and M3. Also, future research may include other determinants, such as interest rates on long-term domestic and foreign currency deposits, and interest rates on treasury bills. Econometric techniques that researchers could use in the future should be either a two or three least squares method, the generalized method of moments or the autoregressive distributed lag (ARDL).

The results obtained in this paper can provide useful policy guidelines to central banks in their quest for price stability. The central banks of the selected Western Balkan countries should carefully monitor the exchange rate as a leading monetary policy indicator because this determinant is among the most important drivers of money demand both in the short run and the long run.

\section{References}

Anusic, Z. 1995. The Determinants of Money Demand in Croatia and Simulation of the Post-Stabilization Period. Croatian Economic Survey 15(2): 85-120.

Arango, S. and Nadiri, I. 1981. Demand for Money in Open Economies. Journal of Monetary Economics 7(1): 69-83.

Babic, A. 2000. The monthly Transaction Money Demand in Croatia. Working paper. Croatian National Bank: 1-46.

Bahmani-Oskooee, M. and Shabsigh, G.1996. The Demand for Money in Japan: Evidence from Cointegration Analysis. Japan and the World Economy 8 (1): 1-10.

Baltagi, B.H. 2001. Econometric Analysis of Panel Data (second edition). Chichester:John Wiley and Sons.

Baltagi, B. H. 2005. Econometric Analysis of Panel Data (third edition). England: John Wiley and Sons, Ltd.

Banerjee, A. 1999. Panel Data Unit Roots and Cointegration: An Overview. Oxford Bulletin of Economics and Statistics 61 (S1): 607-629.

Brown, R.L., Durbin, J. and Evans J. M. 1975. Techniques for Testing the Constancy of Regression Relationships over Time. Journal of the Royal Statistical Society: 149-192.

Bruggeman, A. 2000. The stability of EMU-Wide money demand functions and the monetary policy strategy of the European Central Bank. Manchester School 68(2): 184-202.

Campbell, J. Y. and Perron, P. 1991. Pitfalls and opportunities: what macroeconomists should know about unit roots. Macroeconomics Annual. National Bureau of Economic Research 6: 141-201.

Calvo, G. and Rodriguez, C. 1977. A model of exchange rate determination under currency substitution and rational expectation. Journal of Political Economy 85: 617-625.

Cziraky, D. and Gillman, M. 2006. Money Demand in an EU Accession Country: A VECM Study of Croatia. Bulletin of Economic Research 58 (2): 105-127.
Dobnik, F. 2011. Long-run Money Demand in OECD Countries. RUHR Economic Paper 237.

Dreger, C. Reimers, H.E. and Roffia, B. 2007. Long-Run Money Demand In The New EU Member States With Exchange Rate Effects. Eastern European Economics 45 (2): 75-94.

Dreger, C, D. and Wolters, J. 2009. M3 velocity and asset prices in the euro area, Empirica 36 (1): 51-63.

Ericsson, N. R. 1998. Empirical modelling of money demand. Empirical Economics 23 (3): 295-315.

Harris, R. and Sollis, R. 2003. Applied time series modelling and forecasting. Chichester: J. Wiley.

Hosein, S. 2007. Demand for money in Iran: An ARDL approach. MPRA Paper No. 8224, University Library of Munich, Germany.

Im, K.S. Pesaran, M.H. and Shin, Y. 2003. Testing for Unit Roots in Heterogeneous Panels. Journal of Econometrics 115 (1): 53-74.

Ivanov. M., Petkovski. M. and Naumovska. E., 2015. Money in the Utility Function: Model Simulations and Money Demand Estimation in the Case of the Republic of Macedonia. The South East European Journal of Economics and Business 9 (2): 7-20.

Judd, J. P. and Scadding, J. 1982. The Search for a Stable Money Demand Function: A Survey of the Post-1973 Literature. Journal of Economic Literature 20 (3): 993-1023.

Karla, S. 1998. Inflation and Money Demand in Albania. IMF Working Paper, WP 98/101.

Kejriwal, M. and Perron, P. 2008. Data dependent rules for selection of the number of leads and lags in the dynamic OLS cointegrating regression. Econometric Theory 24 (05):1425-41.

Kjosevski, J. 2013. The Determinants and Stability of Money Demand in Republic of Macedonia. Zbornik radova Ekonomskog Fakulteta u Rijeci 31 (1):35-54.

Komárek, L. and Melecký, M. 2001. Demand for Money in the Transition Economy: The Case of the Czech Republic 1993-2001. Warwick Economic Research Papers 614.

Kumar, S. 2010. Panel data estimates of the demand for money in the pacific island countries. EERI Research Paper Series No: 2010-12.

Maddala, G.S. and Wu, S. 1999. A Comparative Study of Unit Root Tests with Panel Data and a new simple test, Oxford Bulletin of Economics and Statistics 61 (S1): 631-652.

Mankiw, G. N. and Summers L. H. 1986. Money Demand and the Effects of Fiscal Policies. Journal of Money, Credit and Banking 18 (1): 415-429.

Maravić, J. and Palić, M. 2005. Analiza tražnje za novcem u Srbiji, Narodna Banka Srbije.

Mehrotra, A. N. 2008. Demand for money in transition: Evidence from China's disinflation. International Advances in Economic Research 14 (1): 36-47. 
Mark, N. C. and Sul, D. 2003. Cointegration vector estimation by panel DOLS and longrun money demand. Oxford Bulletin of Economics and Statistics 65 (5): 655-680.

Nautz, D. and Rondorf, U. 2011. The (in)stability of money demand in the Euro Area: Lessons from a cross-country analysis, Emperica 38 (4): 539-553.

Ozturk, I. and Acaravci, A. 2008. The Demand for Money in Transition Economies. Romanian Journal of Economic Forecasting 2: 35-43.

Owoye, O. and Onafowora, O. A. 2007. M2 targeting, money demand, and real GDP growth in Nigeria: do rules apply. Journal of Business and Public Affairs 1 (2):1-20.

Payne, J. E. 2000. Post Stabilization Estimates of Money Demand in Croatia: The role of Exchange Rate and Currency Substitution. Ekonomski pregled 51 (11-12): 1352-1368.

Payne, J. E. 2003. Post stabilization estimates of money demand in Croatia: error correction model using the bounds testing approach. Privredna kretanja i ekonomska politika 12 (93): 39-53.

Pedroni, M. 1995. Equivalence of the Drinfeld-Sokolov reduction to a bi-Hamiltonian reduction. Letters in Mathematical Physics 35 (4): 291-302.
Pedroni, P. 2000. Fully-Modified OLS for heterogeneous cointegrated Panels, Advances in Econometrics 15: 93-130.

Skrabic, B. P. and Tomic-Plazibat, N. 2009. Evidence of the Long-run Equilibrium between Money Demand Determinants in Croatia. International Journal of Human and Social Sciences 4 (16): 1177-1181.

Sonje, V. 1999. Esej o monetarnim eksperimentima, ili: kako izabrati monetarni rezim u kasnoj fazi tranzicije. Economic Trends and Economic Policy 9 (74): 41-72.

Stock, J. H. and Watson, M.W. 1993. A Simple Estimator of Cointegrating Vectors in Higher Order Integrated Systems. Econometrica: Journal of the Econometric Society 61: 783-820.

Valadkhani, A. 2008. Long- and Short-Run Determinants of the Demand for Money in the Asian-Pacific Countries: An Empirical Panel Investigation. Annals of Economics and Finance 9 (1): 77-90.

Wagner, M. and Hlouskova, J. 2010. The performance of panel cointegration methods: Results from a large scale simulation study. Econometric Reviews 29 (2): 182-223. 